\title{
The Effectiveness of Task Assessment Standard (TASk) in the Teaching and Learning Process of Physical and Health Education Teachers
}

\author{
Mohd Izwan Shahril \\ Faculty of Sports Science and Coaching \\ Sultan Idris Education University \\ Perak, Malaysia \\ izwan.shahril@fsskj.upsi.edu.my \\ Shaharudin Abdul Aziz \\ Faculty of Sports Science and Coaching \\ Sultan Idris Education University \\ Perak, Malaysia \\ shaharudin@fsskj.upsi.edu.my
}

\author{
Norkhalid Salimin \\ Faculty of Sports Science and Coaching \\ Sultan Idris Education University \\ Perak, Malaysia \\ norkhalid@fsskj.upsi.edu.my \\ Saryono \\ Faculty of Sport Sciences \\ Universitas Negeri Yogyakarta \\ Yogyakarta, Indonesia \\ saryono@uny.ac.id
}

\begin{abstract}
-the purpose of this study is to investigate the effectiveness of Task Assessment Standard (TASk) in the teaching and learning process of Physical and Health Education teachers. Task Assessment Standard (TASk) was constructed based on the Physical and Health Education Content Standard Document (2017). In addition, Malaysia Education Blueprint (2013-2025) and Professional Circular Letter No. 3/1999 (Ministry of Education, 1999) related to the preparation of teaching and learning records were also used in the construction of the TASk. The instrument was measured based on the expert validity value $(r=.85, N=10)$ and the reliability value of TAS $(83 \%, S D=0.68, N=17)$ which are based on the inter observer agreement. The overall student achievement level was $85 \%$ and the strength TASk was also investigated through triangulation ( $85 \%$ ). In conclusion, TASk can be used as a standard and standardized assessment instrument in students' task assessment, in line with the aspiration of the National Education Philosophy to produce balanced individuals from physical, emotional, spiritual and intellectual aspects. The Task Assessment Standard (TASk) can also be used as a guide for Physical Education and Health Education teachers to improve the quality of teaching and learning assessment.
\end{abstract}

Keywords-task assessment standard (TASk), physical and health education teachers, assessment, teaching and learning

\section{INTRODUCTION}

Physical Education and Health Education is a subject that can create holistic values among students. Therefore, it should be a core subject and compulsory to be taught based on the Education Act of 1996 through the Professional Circular Letter No. 25/1998 (Ministry of Education, 1998). This is in line with Mohd Izwan et al (2015), Norkhalid et al (2001), Darst \& Pangrazi (2006), Abdullah Sani (2003), Freeman (2001) and Daeur \& Pangrazi (1995) who states that the subject of Physical Education (PE) contributes to the overall growth and development of students through cognitive, psychomotor and affective-based learning experiences. This can be seen if students' achievement can be assessed comprehensively during the teaching and learning process. To determine the learning achievement, a form of measurement and assessment should be carried out by the teachers.

Teachers are required to conduct assessments in order to determine the achievement of goals and objectives in PHE subject. According to Mohd Izwan et al (2015), Norkhalid et al (2014) and Bhasah (2007), assessment aims to determine the status of an object and compare the status in respect to a set of standards or criteria for decision making. In this context, assessment is a process that includes objective determination, information gathering, information processing and conclusion making (Mohd Izwan et al 2015, Norkhalid et al., 2015). This was also mentioned by Abu Bakar \& Bhasah (2008), that when systematic and scientific assessment is conducted, the decisions made will be more accurate and meet the objective of the assessment results.

The implementation of Standard based Curriculum introduced by Malaysia Ministry of Education (MOE) is a transformation aimed at enhancing the quality of students holistically. The emphasis of the effort focuses on the mastery of $4 \mathrm{M}$ literacy in reading, writing, calculating and reasoning. In addition, students are also exposed to the basic skills of information technology, physical development, cognitive, attitudes and values. In this regard, the transformation of the teaching and learning process as well as the student-centered assessment methodology should be addressed at all school levels so that they are of high quality in line with the hope of MOE.

Hence, the teaching and learning process involves $4 \mathrm{M}$ activities, especially in the PE subject, sh $x$ should be applied at all school levels in Malaysia. As such, Task Assessment Standard (TASk) is tailor-made for teachers and future educators as well as individuals who are directly involved in the field of education for the process of assessing and evaluating students in PHE subject. This instrument is an assessing guideline for reasoning activities in the tasks given by the teacher based on the PHE curriculum. This is because formal summative assessments are also used and the results 
of student achievement need to be recorded in student report books.

In conclusion, the competency level of the quality of assessment and evaluation among teachers needs to be dynamic so that knowledge can be developed effectively. Indirectly, teachers can identify the best methods of teaching and weaknesses can be overcome to as well. To ensure the quality effect of teaching and learning process, teachers need to know their weaknesses through standardized and comprehensive assessment of their teaching methods.

\section{RESEARCH OBJECTIVES}

The objectives of this study are as follows:

1) To identify the value of the validity of the Task Assessment Standard (TASk) in the teaching and learning process of Physical and Health Education teachers.

2) To identify the value of reliability of inter observer agreement between the Task Assessment Standard (TASk) in the teaching and learning process of Physical and Health Education teachers.

3) To identify the level of student learning achievement based on the use of Task Assessment Standard (TASk).

4) To identify the strength of Task Assessment Standard (TASk) in the teaching and learning process of Physical and Health Education teachers on students' achievement, expert panel reports and teachers' consent via triangulation methodology.

\section{RESEARCH THEORIES}

Task Assessment Standard (TASk) was built based on the Secondary School Physical and Health Education (PHE) Standard Curriculum and Assessment Document (2017). In addition, Malaysia Education Blueprint (2013-2025) and Professional Circular Letter No. 3/1999 (Ministry of Education, 1999) in relation to the preparation of teaching and learning records were also used in the construction of the TASk. These three resources were used as guide and reference so that the instrument constructed suits the requirement of Physical and Health Education (PHE) curriculum.

\section{RESEARCH METHODOLOGY}

The pre-experimental method of the one-shot case study was employed as the design of this study. The sample of the research consisted of 10 expert panels, 18 Physical and Health Education teachers and 30 Form 1 students. The selection of expert panel samples, teacher samples and student samples were conducted using purposive sampling method.

The construction of TASk was guided by 6 steps so that the instrument fulfills the specified quality. The steps are as follows:

\section{Step One}

Document analysis was used to obtain the best criteria for students' assessment. To obtain the best criteria, the Secondary School Physical and Health Education (PHE) Standard Curriculum and Assessment Document (2017), Malaysia Education Development Plan (2013-2025) and the Professional Circular Letter No. 3/1999 (Ministry of Education Malaysia, 1999) were used as the primary sources of assessment criteria.

2. Step Two

The next process was to design the suitable criteria and rubric of TASk based on the tasks given to the students. It involved 5 criterias which are; information filtering, generating of new ideas, idea organisation, articulating and referencing. In addition, the level of mastery was based on 5 scales; 1 (Very weak), 2 (Weak), 3 (Satisfactory), 4 (Good) and 5 (Very Good).

\section{Step Three}

Next, the criteria and rubric of TASk that have been constructed was referred to 2 content experts, 2 implementing experts and 2 language experts. All reviews from these experts were taken after TASk was reviewed. After the review, TASk was referred back to 4 other experts to re-evaluate the quality of the instrument.

\section{Step Four}

The process of obtaining the reliability of the inter observer agreement was conducted on 18 PEHE teachers. The interobserver agreement value was based on Mohd Izwan et al (2015), Norkhalid et al (2014) and Rink (2002) who stated that the reliability value adopted is at least $70 \%$ of the agreement between the intero bservers.

\section{Step Five}

The tasks of 30 students were assessed using TASk to see how far it affects teachers in the student assessment process. The data was analyzed along with the validity and reliability values to see the strength of TASk through triangulation methodology.

\section{Final Step}

After the validity value, the reliability value, student achievement level and the strength of TASk were obtained, the instrument can be used as a standard and standardized assessment instrument to assess the level of student achievement through the tasks given by the Physical Education teacher.

\section{Results Of The StUdy}

Identifying the validity value of the Task Assessment Standard (TASk)

The validity value of the Task Assessment Standard (TASk) was obtained from 6 expert panels (Expert 1 and 2 were content experts, Experts 3 and 4 were language experts and Experts 5 and 6 were implementing experts) who assessed it by using a semantic scale validity questionnaire 
(Sidek \& Jamaludin, 2005) that has 11 points. Point 10 (strongly agree), point 0 (strongly disagree) and point 5 is the midpoint. TASk was reviewed based on the feedback received from the selected panel of experts. The content validity value is shown in Table 1 . The calculation of the expert panel validity values was calculated based on the following formula:

\section{Total Expert Score $\times 100 \%=$ Content Validity Achievement Maximum Score}

TABLE I. ALPHA CHRONBACH VALIDITY VALUE (r) OF EXPERT PANEL ITEM

\begin{tabular}{|c|c|c|c|c|c|c|c|c|}
\hline & $\begin{array}{c}\text { Expt } \\
\mathbf{1}\end{array}$ & $\begin{array}{c}\text { Expt } \\
\mathbf{2}\end{array}$ & $\begin{array}{c}\text { Expt } \\
\mathbf{3}\end{array}$ & $\begin{array}{c}\text { Expt } \\
\mathbf{4}\end{array}$ & $\begin{array}{c}\text { Expt } \\
\mathbf{5}\end{array}$ & $\begin{array}{c}\text { Expt } \\
\mathbf{6}\end{array}$ & $\Sigma$ & $\boldsymbol{M}$ \\
\hline $\begin{array}{c}\text { Instructional } \\
\text { Content }\end{array}$ & 0.84 & 0.83 & 0.85 & 0.81 & 0.86 & 0.85 & 5.04 & 0.84 \\
\hline Design & 0.87 & 0.85 & 0.86 & 0.81 & 0.86 & 0.87 & 5.12 & 0.86 \\
\hline $\begin{array}{c}\text { Technical } \\
\text { Writing }\end{array}$ & 0.84 & 0.87 & 0.84 & 0.84 & 0.86 & 0.89 & 5.14 & 0.86 \\
\hline Total & 0.85 & 0.85 & 0.85 & 0.82 & 0.86 & 0.87 & 5.10 & 0.85 \\
\hline
\end{tabular}

Based on Table 1, the validity value of Task Assessment Standard (TASk) was $\mathrm{r}=.85(\mathrm{n}=6)$. According to Mohd Izwan et. al. (2015), Norkhalid et. al. (2014), Sidek \& Jamaludin (2005), Abu Bakar (1985) and Tuckman \& Waheed (1981), the value of 0.70 is considered mastery or reachs a high level. All experts' opinion based on the findings were reviewed for improvement and the researchers once again handed the instrument to four other panel of experts to evaluate the validity of the content as shown in Table 2.

TABLE II. ALPHA CHRONBACH VALIDITY VALUE (r) OF EXPERT PANEL ITEM (REVIEWED)

\begin{tabular}{|c|l|c|}
\hline Content Item & \multicolumn{1}{|c|}{ Validity Value } & $\boldsymbol{M}$ \\
\hline & Expert1 $r=0.84$ & \\
Task Assessment & Expert 2 $r=0.84$ & \multirow{2}{*}{0.85} \\
Standard (TASk) & Expert 3 $r=0.83$ & \\
& Expert 4 $r=0.89$ & \\
\hline
\end{tabular}

Table 2 shows the validity value of expert panels (reviewed) for Task Assessment Standard (TASk) was $\mathrm{r}=$ $0.85(\mathrm{n}=4)$. The findings show that the instrument achieved high validity. The views given by the expert panel were taken into consideration for improvement in compliance with the requirements of Physical and Health Education curriculum.

\section{Identifying the reliability value of the interobserver agreement of Task Assessment Standard (TASk)}

The reliability of a test can provide a consistent result after repeated testing. This is supported by Mohd Izwan et al (2015), Norkhalid et al (2014), Ahmad (2004), Baumgartner \& Jackson (1999) and Miller (2006) who stated a stable and accurate data from the reliability of a test.

Based on Mohd Izwan et al(2015), Norkhalid et al (2014) and Bryington et al (2002), there are two methods for obtaining the value of the interobserver agreement, which are the agreement percentage and Kappa's method. Kappa method is used when the data is obtained applies the nominal scale. According to Mohd Izwan et al(2015), Norkhalid et al (2014) and Rink (2002), if there is more than one observer for a test item then the agreement percentage method is appropriate. This study used the inter observer agreement percentage as shown in the following formula:

Referring to Cohen (1988), the researcher determined the sample size of a teacher's subject $(\mathrm{N}=1)$ at power level $=.80, \mathrm{~d}=1.0$, two-tailed $(\alpha=.05)$. The selection of student subject $(\mathrm{N}=255)$ is 'intact' based on selected teacher sample. It means that all the students in the class taught by the teacher sample automatically become the subject of the study.

The reliability value of inter observer reliability was based on students' task assessment in the topic of Physical Fitness contained in PHE subject. The task was assessed using the Task Assessment Standard (TASk). Students will be given marks based on the tasks assessed by teachers, based on the rubric contained in TASk.

The percentage of inter observer agreement was obtained using the following formula:

\section{Interobserver Agreement $=\frac{\text { Number of Agree }}{\text { Number (agree }+ \text { disagree) }} \times 100$}

The percentage of inter observer agreement for TASk was between $\mathrm{M}=83 \%$ ( $\mathrm{SD}=0.68)$. According to Mohd Izwan et al (2015), Norkhalid et al (2014) and Rink (2002), the reliability value adopted is at least $70 \%$ of the agreement between the observers.

\section{Identifying the level of students learning achievement}

The level of students learning achievement based on task assessed by the teacher using the Task Assessment Standard (TASk), based on the topic of Physical Fitness embedded in the secondary school PHE subject. The selection of student subject $(\mathrm{N}=255)$ was 'intact' based on selected teacher sample. Students achievement is as shown in Table 3.

\section{TABLE III. The Percentage of Students ACHIEVEMENT} LEVEL

\begin{tabular}{|l|c|c|}
\hline Assessment Criteria & \% Achievement & \% $\boldsymbol{M}$ \\
\hline Information filtering & 87 & \\
New Ideas Generating & 83 & \\
Idea Organizing & 87 & 85 \\
Articulating & 87 & \\
Referencing & 81 & \\
\hline
\end{tabular}

\section{Identifying the Strength of Task Assessment Standard (TASk)}

The strength Task Assessment Standard (TASk) was based on students achievement, expert panel value and reliability value through triangulation methodology. The level of inter observer agreement was used to see the overall assessment percentages for students learning achievement, expert panel reports and teacher agreement. Thus, the strength of TASk was analyzed based on Mohd Izwan et al (2015), Norkhalid et al (2014) and Bryington (2002) who stated that if there is more than one observer for a test item, 
then the percentage agreement method is appropriate to be used in obtaining the value of the instrument.

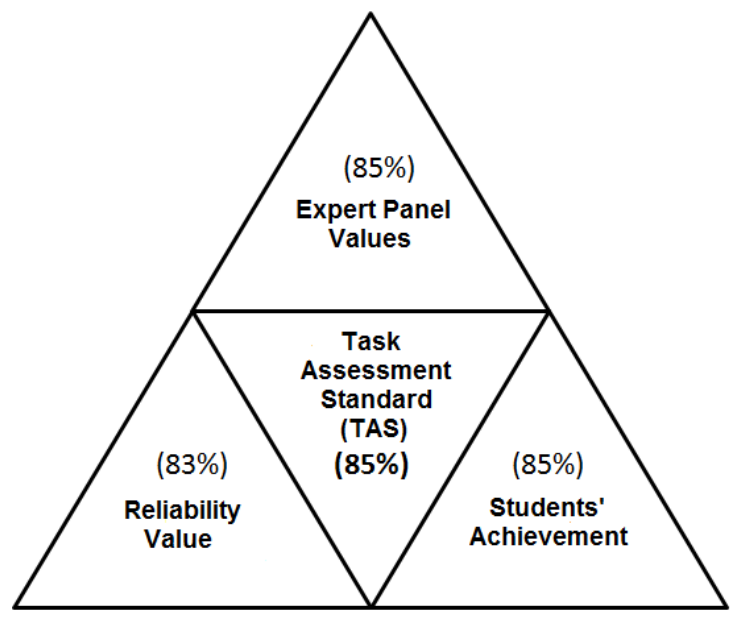

Fig. 1. Mean Percentage of the Strength of Task Assessment Standard (TASk) through triangulation methodology

Based on Figure 1, the overall percentage mean value for all three values was $85 \%$. According to Mohd Izwan et al (2015), Norkhalid et al (2014) and Rink (2002), the value of reliability adopted is at least $70 \% \mathrm{f}$ interobserver agreement. The findings show that Task Assessment Standard (TASk) can be used as one of the standardized assessment instrument of Physical and Health Education (PHE) in accordance with National Education Philosophy.

\section{CONCLUSION}

In overall, Task Assessment Standard (TASk) is suitable to be used as a standard instrument in assessment of students' achievements in Physical and Health Education. TASk is able to assess the assessment quality, evaluate the teachers holistically and have impact on the level of students' achievement in Physical Education, in line with the National Education Philosophy, in producing a holistic human in terms of physical, emotional, spiritual and intellectual. Therefore, TASk can be used as a guide for teachers' improvement in the quality of assessment and evaluation in realizing the goal.

\section{REFERENCES}

[1] A. B. Nordin Penilaian afektif. Kajang: Masa Enterprise. 1985.

[2] A. B. Nordin \& B. A. Bakar, Penaksiran Dalam Pendidikan \& Sains Sosial. Tanjong Malim:Penerbit UPSI. 2008.

[3] A. S.Yahya, Siri pentadbiran pendidikan. Mengurus sekolah. Pahang: PTS Publications. 2003.

[4] A. A. Bryington, J. P. Darcy and W. W. Marley, The estimation of interobserver agreement in behavioral assessment. The Behavior Analyst Today, 2002. 3(3), 323-328. Diperoleh Julai 9, 2010 daripada http://www.public.asu.edu/ mwwatkin/Papers/Kappa(BAT2002).pdf.

[5] P. W. Darst, \& R. P. Pangrazi, Dynamic Physical Education for Secondary School Student $5^{\text {th }}$ ed. Massachusetts: Allyn \& Bacon. 2006.

[6] V. P. Dauer, \& R. P. Pangrazi, Dynamic physical education for elementary school children $\left(11^{\text {th }} e d.\right)$. Massachusetts: Allyn and Bacon. 1995.

[7] Freeman, Physical education and sport in a changing Society $\left(6^{\text {th }} e d\right)$. San Francisco: Benjamin Cummings. 2001.

[8] Kementerian Pendidikan Malaysia Pelan Pembangunan Pendidikan Malaysia 2013-2025. 2012.

[9] Mohd Izwan, Norkhalid \& Gunathevan a/l Elumalai, "The Validity and Realibility of ISO Test Toward The Performance Assessment of Future Physical Education Teachers in Teaching and Learning Process," Science Direct Procedia-Social and Behaviorial Sciences 00 (2015) 000-000. 2015.

[10] N. Salimin, J. Jani, N. A. Ishak, S. Hassan, G. Elumalai, O. K. Boon \& M. I. Shahril "Validity and Reliability of Comprehensive Assessment Instruments for Professional Skills in Field and Court Sport Among Major Students Coaching Based on Model K. International Journal of Humanities, Arts, Medicine and Sciences (BEST: IJHAMS) ISSN(E): 2348-0521, 2014, Vol. 2, Issue 4, Apr 2014, 37-44

[11] Pusat Perkembangan Kurikulum Dokumen Standard Kurikulum dan Pentaksiran Pendidikan Jasmani dan Pendidikan Kesihatan Sekolah Menengah.. Kuala Lumpur: Kementerian Pendidikan Malaysia. 2017.

[12] Pusat Perkembangan Kurikulum Sukatan pelajaran rendah dan menengah. Kuala Lumpur: Kementerian Pendidikan Malaysia. 1999.

[13] J. E. Rink, Teaching physical education for learning $4^{\text {th }}$ ed. New York: McGraw Hill. 2002.

[14] S. M. Noah \& J. Ahmad Pembinaan modul bagaimana membina modul latihan dan modul akademik. Penerbit UPM: Serdang, Selangor. 2005.

[15] B. W. Tuckman, \& M. A. Waheed, Evaluation an individualized science programme for community collage students. Journal of Research in Science Teaching, 18, 489-495. 1981. 